\title{
RESEARCH
}

Open Access

\section{Fibrinolysis protease receptors promote activation of astrocytes to express pro- inflammatory cytokines}

Paola Pontecorvi ${ }^{1,2 \dagger}$, Michael A. Banki ${ }^{1 \dagger}$, Carlotta Zampieri ${ }^{1,3}$, Cristina Zalfa ${ }^{1}$, Pardis Azmoon ${ }^{1}$, Maria Z. Kounnas ${ }^{1}$, Cinzia Marchese ${ }^{2}$, Steven L. Gonias ${ }^{*^{*}}$ and Elisabetta Mantuano ${ }^{*^{*}}$ (D)

\begin{abstract}
Background: Astrocytes contribute to the crosstalk that generates chronic neuro-inflammation in neurological diseases; however, compared with microglia, astrocytes respond to a more limited continuum of innate immune system stimulants. Recent studies suggest that the fibrinolysis system may regulate inflammation. The goal of this study was to test whether fibrinolysis system components activate astrocytes and if so, elucidate the responsible biochemical pathway.
\end{abstract}

Methods: Primary cultures of astrocytes and microglia were prepared from neonatal mouse brains. The ability of purified fibrinolysis system proteins to elicit a pro-inflammatory response was determined by measuring expression of the mRNAs encoding tumor necrosis factor-a (TNF- $a$ ), interleukin-1 $\beta$ (IL-1 $\beta$ ), and chemokine (C-C motif) ligand 2 (CCL2). IKBa phosphorylation also was measured. Plasminogen activation in association with cells was detected by chromogenic substrate hydrolysis. The activity of specific receptors was tested using neutralizing antibodies and reagents.

Results: Astrocytes expressed pro-inflammatory cytokines when treated with plasminogen but not when treated with agonists for Toll-like Receptor-4 (TLR4), TLR2, or TLR9. Microglia also expressed pro-inflammatory cytokines in response to plasminogen; however, in these cells, the response was observed only when tissue-type plasminogen activator (tPA) was added to activate plasminogen. In astrocytes, endogenously produced urokinase-type plasminogen activator (UPA) converted plasminogen into plasmin in the absence of tPA. Plasminogen activation was dependent on the plasminogen receptor, a-enolase, and the UPA receptor, UPAR. Although UPAR is capable of directly activating cellsignaling, the receptor responsible for cytokine expression and IKBa phosphorylation response to plasmin was Proteaseactivated Receptor-1 (PAR-1). The pathway, by which plasminogen induced astrocyte activation, was blocked by inhibiting any one of the three receptors implicated in this pathway with reagents such as EACA, a-enolase-specific antibody, uPARspecific antibody, the UPA amino terminal fragment, or a pharmacologic PAR-1 inhibitor.

Conclusions: Plasminogen may activate astrocytes for pro-inflammatory cytokine expression through the concerted action of at least three distinct fibrinolysis protease receptors. The pathway is dependent on UPA to activate plasminogen, which is expressed endogenously by astrocytes in culture but also may be provided by other cells in the astrocytic cell microenvironment in the CNS.

Keywords: Astrocyte, Microglia, Inflammation, Plasminogen, Tissue-type plasminogen activator, Urokinase-type plasminogen activator, UPAR, a-Enolase, Protease-activated receptor

\footnotetext{
*Correspondence: sgonias@ucsd.edu; emantuano@ucsd.edu

†Paola Pontecorvi and Michael A. Banki contributed equally to this work.

'The Department of Pathology, University of California San Diego, 9500

Gilman Drive, La Jolla, CA 92093-0612, USA

Full list of author information is available at the end of the article
}

(c) The Author(s). 2019 Open Access This article is distributed under the terms of the Creative Commons Attribution 4.0 International License (http://creativecommons.org/licenses/by/4.0/), which permits unrestricted use, distribution, and reproduction in any medium, provided you give appropriate credit to the original author(s) and the source, provide a link to the Creative Commons license, and indicate if changes were made. The Creative Commons Public Domain Dedication waiver (http://creativecommons.org/publicdomain/zero/1.0/) applies to the data made available in this article, unless otherwise stated. 


\section{Background}

In the CNS, microglia and astrocytes regulate innate immunity and neuro-inflammation $[1,2]$. By secreting cytokines and other extracellular mediators, these cells establish crosstalk with one another and with local neurons and also recruit inflammatory cells from the blood. Microglia express a large continuum of Pattern Recognition Receptors (PRRs), including diverse members of the Toll-like Receptor (TLR) family [3, 4]. By contrast, astrocytes express a more limited repertoire of PRRs, including only low levels of specific TLRs, such as TLR3 [5-7]. Thus, understanding the signals that lead to astrocyte activation and contribute to neuro-inflammation remains an important problem.

Proteins that function in hemostasis have been implicated in innate immunity and in the regulation of inflammation, including Tissue Factor, Fibrinogen, and Protein C [8-11]. The fibrinolysis system is the arm of hemostasis that systematically lyses blood clots and maintains patency in uninjured blood vessels [12]. The principal activators of fibrinolysis are tissue-type plasminogen activator (tPA) and urokinase-type plasminogen activator (uPA), both of which convert plasminogen (Plg) into plasmin (PM), which degrades fibrin $[12,13]$. In recent years, cellular receptors for fibrinolysis proteases and their zymogens have been identified. A family of structurally diverse but functionally similar receptors for Plg have been characterized [14]. These receptors, which in many cases also bind tPA, amplify the rate of Plg activation, localize PM activity to the outer cell membrane, and participate in pathways that result in cell-signaling [14]. The urokinase receptor (UPAR) is a glycosylphosphatidylinositol (GPI)-anchored receptor that increases the catalytic efficiency of Plg by uPA and also associates with transmembrane proteins to form a receptor complex that signals in response to vitronectin and uPA [15]. tPA interacts with a distinct receptor complex that includes the N-methyl-D-aspartate (NMDA) receptor and Low-Density Lipoprotein Receptor-related Protein-1 (LRP1) to trigger cell-signaling and regulate innate immunity $[16,17]$. Finally, it has been shown in studies mainly with monocytes and macrophages that PM directly cleaves GPCRs in the Protease-activated Receptor (PAR family) such as PAR-1 and PAR-2 to regulate innate immunity [18-21]. Cleavage of PAR-1 by PM also has been shown in astrocytes [22]. In these cells, PAR-1 cleavage activates phosphoinositide- 3 kinase (PI3K) and induces expression of transforming growth factor- $\beta 3$ [22]. The function of fibrinolysis receptors in astrocytic activation and their possible effects on neuro-inflammation was the topic of the current study.

We compared microglia and astrocytes isolated from mouse pups and showed that both cell types demonstrate increased expression of pro-inflammatory cytokines, including TNF $\alpha$, interleukin-1 $\beta$ (IL-1 $\beta$ ), and CCL2 when treated with Plg. Plg was active in microglial cultures only when added together with plasminogen activator to generate $\mathrm{PM}$. By contrast, neonatal mouse astrocytes (N-astrocytes), which were not responsive to activators of TLR2, TLR4, or TLR9, expressed increased levels of cytokines in response to $\mathrm{Plg}$ alone. The responsible pathway required uPA, which was expressed endogenously by $\mathrm{N}$-astrocytes, together with a system of fibrinolysis receptors that included the Plg receptor, $\alpha$-enolase, uPAR, and PAR-1. Despite the well-documented role of UPAR in cellsignaling [15], including in astrocytes [23], uPAR apparently functioned only to facilitate $\mathrm{Plg}$ activation in the pathway that resulted in pro-inflammatory cytokine expression. The amino terminal fragment of uPA (ATF), which replicates most of the cell-signaling activity of uPA [24-26], functioned as an antagonist of this pathway. Overall, our results define a multicomponent, linear pathway, involving three distinct fibrinolysis receptors, that couples Plg to astrocytic activation. Although in the adult brain, astrocytes may express decreased levels of uPA, compared with cultured $\mathrm{N}$-astrocytes, astrocytes also may become loaded with uPA that is transferred from neurons [23]. These results suggest novel opportunities for pharmacological modulation of neuro-inflammation.

\section{Materials and methods}

\section{Proteins and reagents}

Glu-Plasminogen was purified from human plasma as previously described [27]. Human tPA, which is produced in $\mathrm{CHO}$ cells and $95 \%$ in the two-chain form, was from Molecular Innovations. Lipopolysaccharide (LPS) serotype 055: B5 from E. coli was from Sigma-Aldrich. The TLR2 ligand, lipoteichoic acid (LTA) from S. aureus and the TLR9 ligand, ODN 1826, were from InvivoGen. Amiloride (AMD) was from Sigma-Aldrich. Mouse uPAR-specific antibody (cat. AF534) and control IgG (cat. AB105C) were from R\&D Systems. $\alpha$-Enolase-specific polyclonal antibody was from Invitrogen (cat. 3810T). Rabbit polyclonal antibody that targets the C-terminus of actin was from SigmaAldrich (cat. A2066). $\varepsilon$-Aminocaproic acid (عACA) was from MP Biomedicals. Aprotinin was from PanReac AppliChem. SCH 79797 was from Cayman Chemicals. The plasmin-specific chromogenic substrate, H-D-Val-Leu-Lysp-nitroanilide (S-2251) and mouse uPA ATF were from Molecular Innovations.

\section{Cell culture}

Microglia and N-astrocytes were isolated from C57BL/6J mouse pups [28]. In brief, brains were harvested from postnatal day 1-6 mice. The cortices were dissected from the forebrain, and the surrounding meninges were removed. Intact cortices were mechanically and enzymatically dissociated using the Neural Tissue Dissociation Kit 
P (Miltenyi Biotec). Mixed glial cultures were established in Dulbecco's modified Eagle's medium/F-12 (DMEM/F12) supplemented with GlutaMAX (Gibco), 10\% fetal bovine serum (FBS, Gibco), and 100 units/ml AntibioticAntimycotic (Gibco). After culturing for 10-14 days, microglia was harvested by shaking at $200 \mathrm{rpm}$ for $30 \mathrm{~min}$ at $37^{\circ} \mathrm{C}$. The floating cells were collected by centrifugation and re-plated at $3 \times 10^{5}$ cells/well. Oligodendrocytes were removed by an additional $6 \mathrm{~h}$ of shaking. Then, Nastrocytes were collected by trypsinization and subsequent centrifugation and re-plated at $3.5 \times 10^{5}$ cells/well on Poly-D-Lysine hydrobromide-coated wells in DMEMHigh Glucose supplemented with 10\% FBS and 100 units/ $\mathrm{ml}$ Antibiotic-Antimycotic. Experiments were performed within $24 \mathrm{~h}$ of completing the isolation procedure for microglia and within $48 \mathrm{~h}$ of completing the isolation procedure for $\mathrm{N}$-astrocytes.

Bone marrow cells were isolated from the femurs of 16-week-old wild-type C57BL/6J male mice, as previously described [29]. Cells were plated in non-tissue culture-treated dishes and cultured in DMEM/F-12 medium containing 10\% FBS and 20\% L929 cellconditioned medium for 8 days. Non-adherent cells were eliminated on day 10. Adherent cells included >95\% bone marrow-derived macrophages (BMDMs) as determined by F4/80 and CD11b immunoreactivity. All reagents used in this study were tested for their effects on viability of cells and had no effect as determined by MTT assay (Invitrogen).

\section{RT-qPCR}

In cytokine expression experiments, microglia and $\mathrm{N}$ astrocytes were cultured in serum-free medium (SFM) for $30 \mathrm{~min}$ and then treated simultaneously for $6 \mathrm{~h}$ with various proteins and reagents, including tPA $(12 \mathrm{nM})$, Plg $(0.2 \mu \mathrm{M})$, LPS $(0.1 \mu \mathrm{g} / \mathrm{mL})$, LTA $(1.0 \mu \mathrm{g} / \mathrm{mL})$, ODN $1826(1.0 \mu \mathrm{g} / \mathrm{mL})$, aprotinin (33 units $/ \mathrm{mL}), \mathrm{SCH} 79797$ $(2 \mu \mathrm{M})$, amiloride $(100 \mu \mathrm{M})$, uPAR-specific antibody $(1 \mu \mathrm{g} / \mathrm{mL}), \quad \alpha$-enolase-specific antibody $(10 \mu \mathrm{g} / \mathrm{mL})$, EACA $(10 \mathrm{mM})$, or the uPA ATF (concentration as indicated). BMDMs were serum-starved for $30 \mathrm{~min}$ and then treated for $3 \mathrm{~h}$ with tPA $(12 \mathrm{nM})$ plus Plg (200 nM), LPS $(0.1 \mu \mathrm{g} / \mathrm{mL})$, LTA $(1.0 \mu \mathrm{g} / \mathrm{mL})$, ODN $1826(1.0 \mu \mathrm{M})$, or vehicle $(20 \mathrm{mM}$ sodium phosphate, $150 \mathrm{mM} \mathrm{NaCl}, \mathrm{pH}$ 7.4). Total RNA was isolated using the NucleoSpin RNA kit (Macherey-Nagel) in the presence of DNAse and reverse-transcribed into cDNA using the iScript cDNA Synthesis Kit (Bio-Rad). RT-qPCR was performed with TaqMan gene expression products and an AB Step One Plus Real-time PCR System (Applied Biosystems). Noreverse transcriptase controls were performed routinely. The primer-probe sets were GAPDH (Mm99999915_ g1), RPL13A (Mm01612986_gH), SDHA (Mm01352366_ m1), TNF $\alpha$ (Mm00443258_m1), IL-1ß (Mm00434228_ m1), and CCL2 (Mm00441242_m1). The relative change in gene expression was calculated using the $2^{-\Delta \Delta \mathrm{Ct}}$ method and GAPDH mRNA as a normalizer.

\section{Immunoblot analysis}

Microglia and astrocytes were extracted in RIPA buffer (PBS with 1\% Triton X-100, 0.5\% sodium deoxycholate, $0.1 \%$ SDS) supplemented with Halt Protease and Phosphatase Inhibitor Cocktails (Thermo Scientific). The protein concentration in cell extracts was determined by DC Protein Assay (Bio-Rad). An equivalent amount of cellular protein was subjected to SDS-PAGE and electro-transferred to polyvinylidene fluoride membranes. The membranes were blocked with 5\% nonfat dry milk in $20 \mathrm{mM}$ Tris- $\mathrm{HCl}, 150 \mathrm{mM}$ sodium phosphate, pH 7.4 with $0.1 \%$ Tween 20 (TBS-T buffer) and incubated with primary antibodies from Cell Signaling Technology, including antibodies that target phosphoI $\mathrm{B} \alpha$ (Ser32) (1:1000, cat. 2859), IкB $\alpha$ (1:1000, cat. 9242), and $\beta$-actin (1:5000, cat. 3700), followed by horseradish peroxidase conjugated secondary antibodies (Jackson ImmunoResearch). Immunoblots were developed using ProSignal Pico and Femto ECL Reagent substrate (Prometheus) and imaged using the Azure Biosystems c300 imaging system.

\section{PM activity assay}

$\mathrm{N}$-astrocytes and microglia were seeded in 48-well plates $\left(1 \times 10^{5}\right.$ cells/well). Other wells were coated with FBS in the absence of cells. After $48 \mathrm{~h}$, cells were washed 3 times and the medium replaced with $\mathrm{HBSS}$ with $\mathrm{Mg}^{+}$ and $\mathrm{Ca}^{2++}$ (Gibco), $10 \mathrm{mM}$ HEPES and $1 \mathrm{mg} / \mathrm{mL}$ bovine serum albumin (BSA), pH 7.4 (H-buffer). Plg, tPA, and/ or amiloride were added as indicated so the final volume was $180 \mu \mathrm{L}$. The concentrations for tPA and amiloride were $12 \mathrm{nM}$ and $100 \mu \mathrm{M}$, respectively. The concentration of Plg was $0.2 \mu \mathrm{M}$. S-2251 $(0.2 \mathrm{mM})$ was added $6 \mathrm{~h}$ later. S-2251 hydrolysis was detected by monitoring the absorbance at $405 \mathrm{~nm}$ as a function of time using a SpectraMax M2 microplate reader.

\section{Plg binding to $\mathrm{N}$-astrocytes}

Human Glu-Plg was labeled with Alexa Fluor 594 (Invitrogen). Labeling reactions were carried out according to the manufacturer's instructions. The total reaction mixture was transferred to a BioGelP-30 fine size exclusion purification resin. PBS was used as an elution buffer to separate Plg-Alexa Fluor 594 conjugate (Plg-594) from free dye. Purified Plg-594 was quantified by measuring the absorbance at $280 \mathrm{~nm}$ and $590 \mathrm{~nm}$ following manufacturer's instructions. $\mathrm{N}$-astrocytes were plated at $1.3 \times$ $10^{4}$ cells/well in 96-well plates in DMEM-high glucose supplemented with $10 \%$ FBS and 100 units $/ \mathrm{ml}$ Antibiotic-Antimycotic. The cells were then transferred 
to $\mathrm{H}$-buffer. Plg-594 was incubated with the cells at $4{ }^{\circ} \mathrm{C}$ with gentle agitation for $4 \mathrm{~h}$. Binding studies were performed at $4^{\circ}$ to minimize Plg activation, which may be associated with the generation of new Plg binding sites [14]. $\varepsilon A C A$ was included in some wells to distinguish specific and non-specific binding [30]. The cells were then washed 3 times with $\mathrm{H}$-buffer. Cell-associated Plg594 was recovered in PBS plus $\varepsilon A C A$ and quantified by fluorescent emission at $617 \mathrm{~nm}$ using an excitation wavelength of $590 \mathrm{~nm}$ and a cut-off filter of $610 \mathrm{~nm}$ in a SpectraMax M2 microplate reader.

\section{Statistics}

Statistical analysis was performed using GraphPad Prism 5.0 (GraphPad Software Inc.). All results are expressed as the mean \pm SEM. RT-qPCR data were analyzed by one-way ANOVA followed by Tukey's multiple comparison test $\left({ }^{*} p<0.05,{ }^{* * *} p<0.01,{ }^{* * * *} p<0.001\right)$.

\section{Results}

\section{$\mathrm{N}$-astrocytes express pro-inflammatory cytokines in response to Plg but not in response to multiple TLR ligands}

$\mathrm{N}$-astrocytes were treated with $12 \mathrm{nM}$ tPA and $0.2 \mu \mathrm{M}$ $\mathrm{Plg}$ for $6 \mathrm{~h}$. Control cells were treated with LPS, which initiates cell-signaling and induces expression of proinflammatory cytokines in a TLR4-dependent manner [31], LTA, which activates TLR2 [32], or ODN 1826, which activates TLR9 [33]. RT-qPCR was performed to assess TNF $\alpha$ mRNA expression. GAPDH mRNA was determined as a normalizer. Figure 1a shows that Plg plus tPA robustly induced TNF $\alpha$ expression whereas the TLR agonists failed to have an effect. Similar results were obtained when we studied expression of CCL2 (Fig. 1b) and IL-1 $\beta$ (Fig. 1c). Because the role of GAPDH as a RT-qPCR normalizer for astrocytes has been called into question [34, 35], we repeated these studies using RPL13A and SDHA as normalizers. Highly similar results were obtained with both alternatives to GAPDH (see Additional file 1: Figure S1A-C). In control experiments, we studied mouse BMDMs. In these cells, Plg plus tPA induced expression of TNF $\alpha$, as in Nastrocytes; however, so did all three TLR agonists, proving that the agonists were active (Fig. 1d).

The response of astrocytes to pro-inflammatory stimuli also was evaluated by examining $I \kappa B \alpha$ phosphorylation, an index of $\mathrm{NF}_{\mathrm{K} B}$ activation [34]. $\mathrm{N}$-astrocytes were treated with Plg plus tPA, LPS, LTA, or ODN 1826 for $1 \mathrm{~h}$. In response to Plg plus tPA, IкB $\alpha$ was phosphorylated and the total abundance of IkB $\alpha$ was decreased (Fig. 1e), indicating NFkB activation. Responses were not observed with any of the TLR agonists. This result was confirmed by densitometry (see Additional file 1: Figure S1D).
Plg activates $\mathrm{N}$-astrocytes independently of exogenously added tPA

In BMDMs, induction of pro-inflammatory cytokine expression by Plg requires simultaneous addition of Plg activator and generation of catalytically active PM [21]. In experiments with cultured microglia, the same result was obtained. TNF $\alpha$ mRNA was robustly increased in cells treated with Plg plus tPA but not in cell treated with tPA or Plg alone (Fig. 1)f. The magnitude of the response of microglia to Plg plus tPA was similar to that observed with $0.1 \mu \mathrm{g} / \mathrm{mL}$ LPS, our positive control. IkB $\alpha$ was phosphorylated and decreased in total abundance in microglia treated with Plg and tPA but not in cells treated with $\mathrm{tPA}$ or Plg alone (Fig. 1g), again indicating that PM generation by exogenously added plasminogen activator is probably required to induce pro-inflammatory cytokine expression by these cells. The magnitude of the response to Plg plus tPA in microglia, as determined by densitometry analysis of the IkB $\alpha$ phosphorylation level and the decrease in total abundance of $\mathrm{I} \kappa \mathrm{B} \alpha$, was similar to that observed with LPS, as determined by densitometry (see Additional file 1: Figure S1E).

When N-astrocytes were treated with $200 \mathrm{nM}$ Plg plus $12 \mathrm{nM}$ tPA or with Plg in the absence of tPA for $6 \mathrm{~h}$, TNF $\alpha$ mRNA expression was increased (Fig.1h). The magnitude of the effect was equivalent in the presence or absence of tPA. tPA alone failed to increase TNF $\alpha$ expression by $\mathrm{N}$-astrocytes. Similar results were obtained when we studied expression of CCL2 (Fig. 1i) and IL-1ß (Fig. 1j). Again, expression of these pro-inflammatory cytokines was increased comparably by Plg plus tPA or by $\mathrm{Plg}$ alone. In the absence of Plg, tPA did not regulate expression of IL- $1 \beta$ or CCL2.

When N-astrocytes were treated with $0.2 \mu \mathrm{M}$ Plg plus 12 nM tPA or with $0.2 \mu \mathrm{M}$ Plg in the absence of tPA for $1 \mathrm{~h}$, $I_{\kappa} B \alpha$ was phosphorylated and the total abundance of IкB $\alpha$ was decreased (Fig. 1k). tPA did not cause IkB $\alpha$ phosphorylation in the absence of Plg. This result was confirmed by densitometry (see Additional file 1: Figure S1F). Figure 11 shows that in response to $\mathrm{Plg}, \mathrm{I} \kappa \mathrm{B} \alpha$ was phosphorylated gradually as a function of time, beginning at $45 \mathrm{~min}$ (see also Additional file 1: Figure S1G). This result is consistent with a model in which the Plg must be modified to initiate cell-signaling, for example by endogenously produced plasminogen activators.

\section{$\mathrm{N}$-astrocytes activate Plg endogenously}

To test whether $\mathrm{N}$-astrocytes express endogenous plasminogen activators that allow Plg activation, we incubated $0.2 \mu \mathrm{M}$ Plg with $\mathrm{N}$-astrocytes, with microglia, and in wells without cells. In some wells, we added $12 \mathrm{nM}$ tPA. After $6 \mathrm{~h}, \mathrm{PM}$ was detected by measuring the rate of hydrolysis of S-2251. In N-astrocyte cultures, similar levels of PM were detected irrespective of whether tPA 


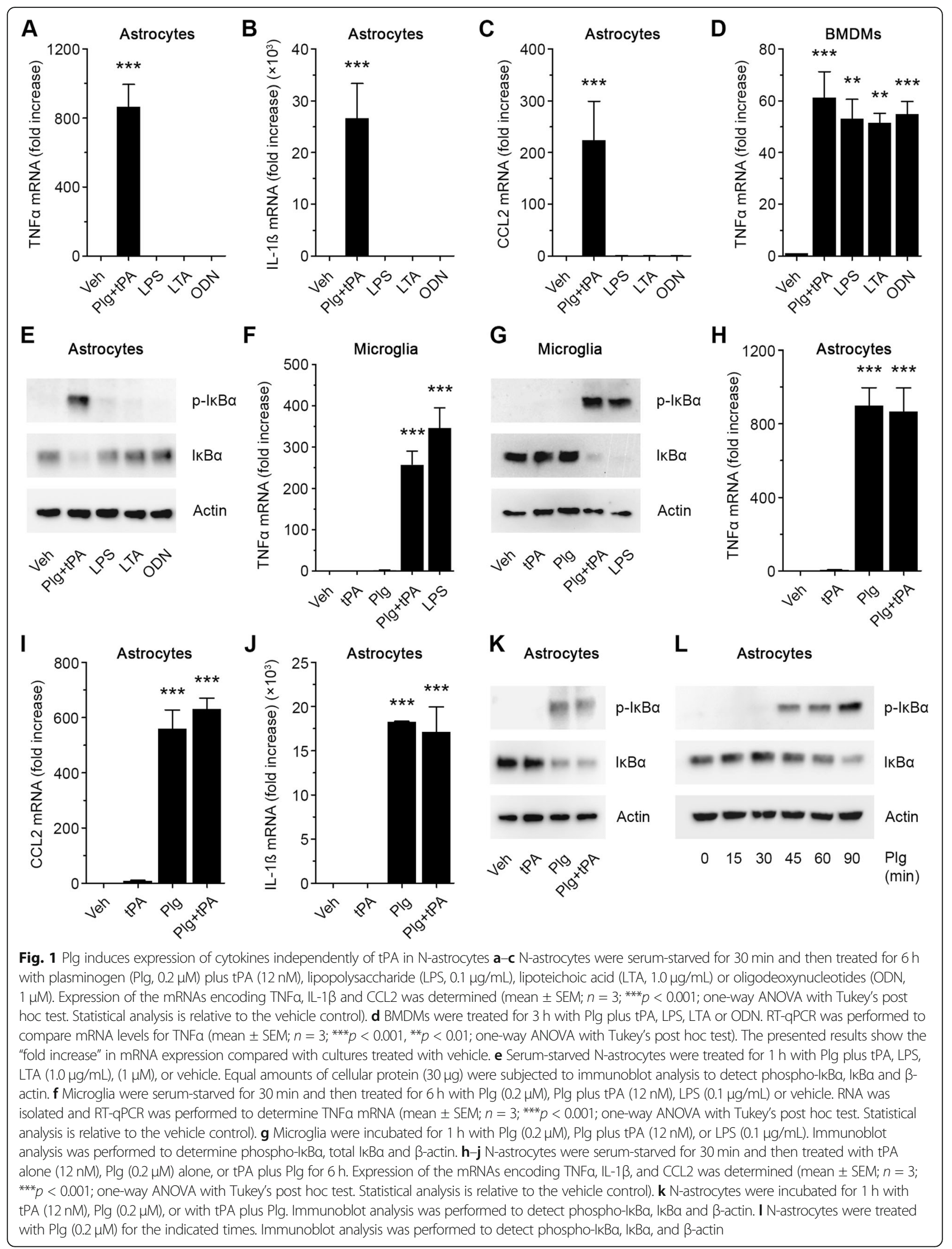


was added or not (Fig. 2a). By contrast, in wells with microglia, PM was detected only when tPA was added together with Plg. The same was true in wells without cells.

To confirm that Plg-induced cytokine expression in $\mathrm{N}$-astrocytes requires $\mathrm{PM}$ generation, we treated $\mathrm{N}$ astrocytes with Plg alone or Plg plus tPA for $6 \mathrm{~h}$ in the presence or absence of the plasmin active site inhibitor, aprotinin. Figures $2 \mathrm{~b}-\mathrm{d}$ show that aprotinin blocked the effects of Plg and Plg plus tPA on expression of TNF $\alpha$, IL-1 $\beta$, and CCL 2 by $\mathrm{N}$-astrocytes. Aprotinin also blocked the ability of Plg and Plg plus tPA to induce I $\kappa$ B $\alpha$ phosphorylation in $\mathrm{N}$-astrocytes (Fig. 2e, Additional file 1: Figure $\mathrm{S} 1 \mathrm{H})$.
Plg receptors are necessary for induction of cytokine expression by $\mathrm{Plg}$

Plg receptors amplify the rate of Plg activation by tPA and UPA [14]. These receptors also may be involved in cell-signaling pathways activated by Plg [21, 35]. Because Plg receptor interactions are dependent on Plg lysinebinding sites, these interactions are competitively inhibited by $\varepsilon A C A$ [30]. Figure 3a shows that $\mathrm{N}$-astrocytes bound fluorescently labeled Plg (Plg-594) in a specific manner, when specific binding was defined by the fraction of bound Plg displaced by $\varepsilon A C A$. The $K_{D}$ for specific binding of Plg-594 to $\mathrm{N}$-astrocytes was $1.0 \pm$ $0.3 \mu \mathrm{M}$, consistent with the known binding affinity of Plg to Plg receptors in other cell types [14]. When N-
A

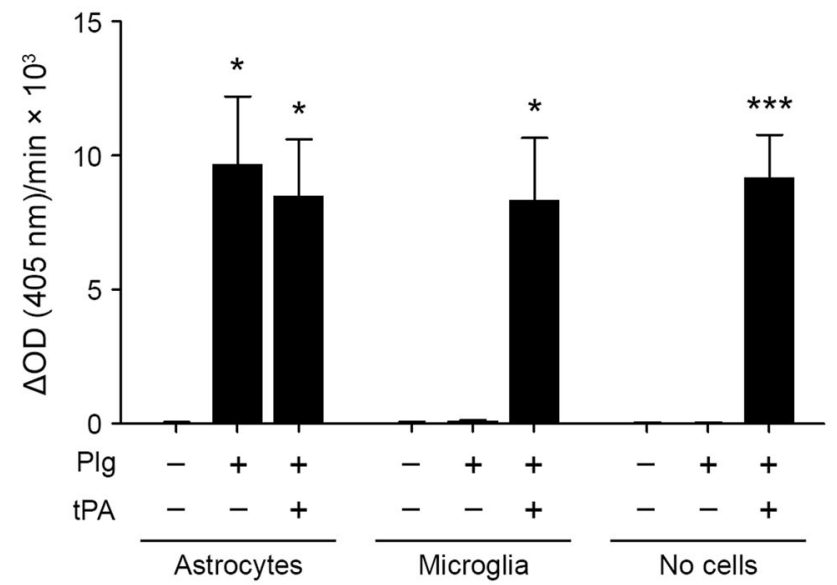

C

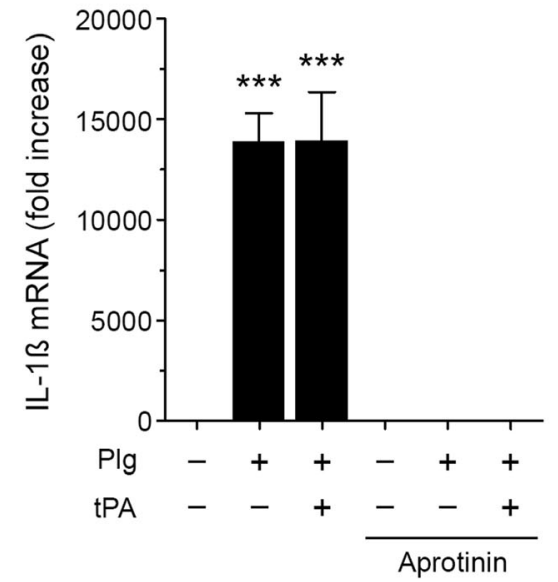

B

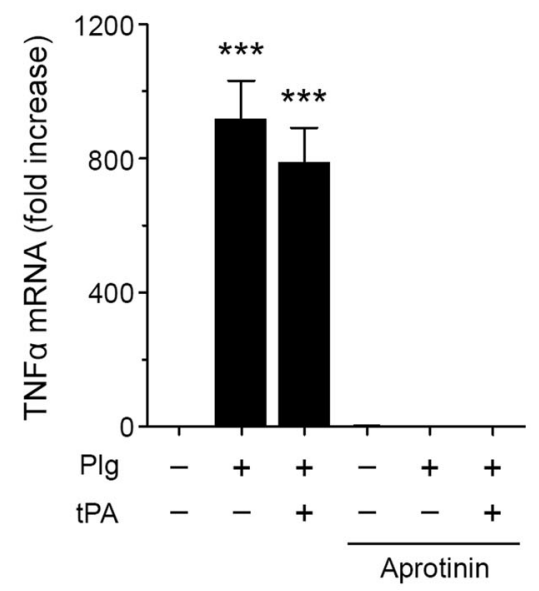

E
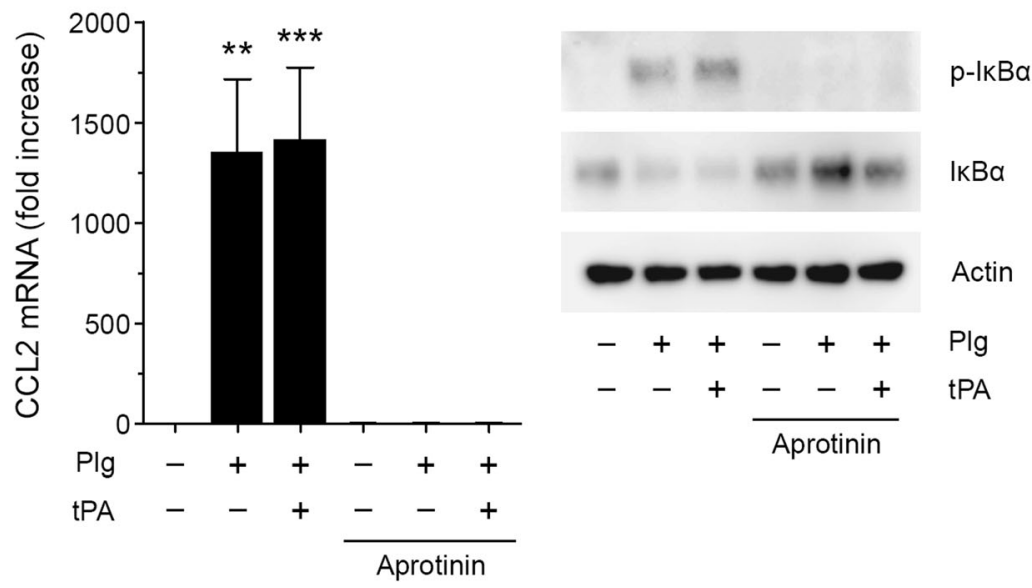

Fig. 2 Plg activation is required for induction of cytokine expression by $\mathrm{N}$-astrocytes. a Plg $(0.2 \mu \mathrm{M})$, Plg plus tPA (12 nM) or vehicle was added to wells with $\mathrm{N}$-astrocytes, microglia, or no cells for $6 \mathrm{~h}$. Then, S-2251 (0.2 mM) was added. The velocity of S-2251 hydrolysis was determined $\Delta$ Abs $405 \mathrm{~nm} / \mathrm{min} \times 10^{3}$ (mean $\pm \mathrm{SEM}, n=3 ;{ }^{* *} p<0.01 ;{ }^{*} p<0.1$ one-way ANOVA with Tukey's post hoc test. Statistical analysis is relative to the vehicle control). b-d N-astrocytes were treated for $6 \mathrm{~h}$ with Plg $(0.2 \mu \mathrm{M})$, Plg plus tPA $(12 \mathrm{nM})$ or vehicle, with and without Aprotinin (33 units/ml). RT-qPCR was performed to determine TNFa, IL-1 $\beta$, and CCL2 mRNA (mean \pm SEM; $n=3 ;{ }^{* * *} p<0.001,{ }^{* *} p<0.01$; one-way ANOVA with Tukey's post hoc test. Statistical analysis is relative to the vehicle control). e N-astrocytes were treated with Plg $(0.2 \mu M)$, Plg plus tPA (12 nM), or vehicle in presence and absence of Aprotinin (33 units/ml) for $1 \mathrm{~h}$. Immunoblot analysis was performed to detect phospho-IKBa, IKBa, and $\beta$-actin 


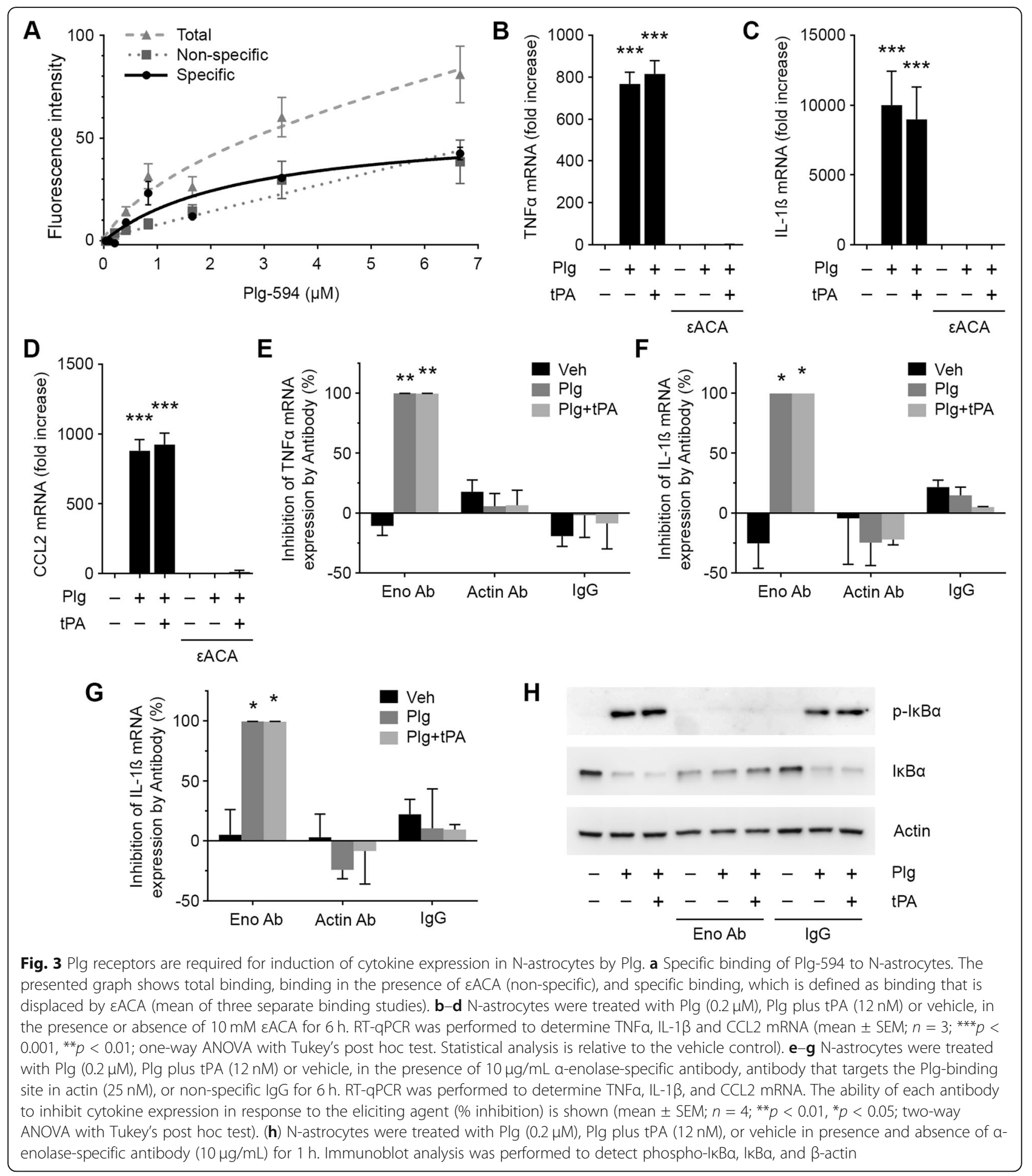

astrocytes were incubated with $\mathrm{Plg}$ alone or with $\mathrm{Plg}$ plus tPA, in the presence of $\varepsilon A C A$, expression of TNF $\alpha$, IL-1 $\beta$, and CCL2 were blocked (Fig. 3b-d). These results suggest that Plg receptors are required for Plg activation and for induction of pro-inflammatory cytokine expression by $\mathrm{PM}$ in $\mathrm{N}$-astrocytes.
The molecular nature of Plg receptors varies from cell type to cell type. In many cell types, $\alpha$-enolase, which is typically an intracytoplasmic protein, translocates to the cell surface and functions as a Plg receptor [36-38]. Like $\alpha$-enolase, actin may translocate to the astrocyte cellsurface and has been reported to bind Plg and amplify 


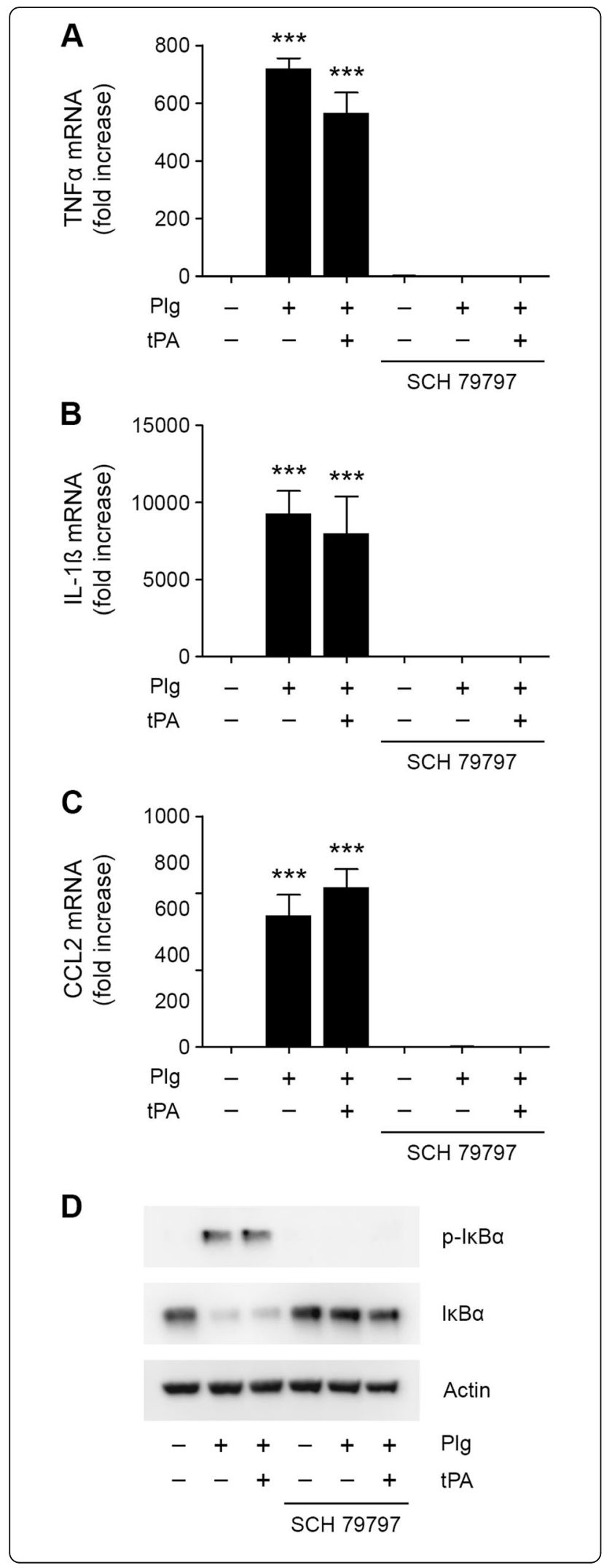

Fig. 4 PAR-1 is essential in the pathway by which PM activates Nastrocytes. (a-c) N-astrocytes were treated with Plg $(0.2 \mu \mathrm{M})$, Plg plus tPA $(12 \mathrm{nM})$ or vehicle in presence and absence of SCH $79797(2 \mu \mathrm{M})$ for $6 \mathrm{~h}$. RT-qPCR was performed to determine expression of TNFa, IL$1 \beta$, and CCL2 (mean \pm SEM; $n=3 ;{ }^{* * *} p<0.001$; one-way ANOVA with Tukey's post hoc test. Statistical analysis is relative to the vehicle control). $\mathbf{d} \mathrm{N}$-astrocytes were treated with Plg $(0.2 \mu \mathrm{M})$, Plg plus tPA $(12 \mathrm{nM})$, or with vehicle, in the presence and absence of SCH $79797(2 \mu \mathrm{M})$ for $1 \mathrm{~h}$. Immunoblot analysis was performed to detect phospho-IKBa, IKBa, and $\beta$-actin

$\mathrm{Plg}$ activation [39]. Figures $3 \mathrm{e}-\mathrm{g}$ show that, in $\mathrm{N}$ astrocytes, $\alpha$-enolase-specific antibody completely blocked expression of TNF $\alpha$, IL-1 $\beta$, and CCL2 in response to Plg or Plg plus tPA. Actin-specific antibody, by contrast, failed to inhibit cytokine expression. Non-specific IgG, at equivalent concentrations, also was without effect. $\alpha$ enolase-specific antibody blocked the ability of $\mathrm{Plg}$ and $\mathrm{Plg}$ plus tPA to induce IkB $\alpha$ phosphorylation in $\mathrm{N}$-astrocytes (Fig. 3h, Additional file 1: Figure S1I), supporting the results of our cytokine expression studies.

\section{PM induces inflammatory cytokine expression in $\mathrm{N}$ - astrocytes via a PAR-dependent pathway}

PAR-1, a G-protein-coupled receptor that is activated by proteolytic cleavage, is strongly expressed in resting as well as reactive astrocytes and plays a key role in the astrocytic response to injury in vivo $[40,41]$. To test whether PARs are involved in the pathway by which Plg induces cytokine expression in $\mathrm{N}$-astrocytes, we treated these cells with the selective PAR-1 antagonist, SCH 79797. SCH 79797 completely blocked expression of TNF $\alpha$, IL-1 $\beta$, and CCL2 in response to Plg or Plg plus tPA (Fig. $4 \mathrm{a}-\mathrm{c}$ ). SCH 79797 also blocked IKB $\alpha$ phosphorylation when $\mathrm{N}$ astrocytes were treated with Plg or Plg plus tPA for $1 \mathrm{~h}$ (Fig. 4d, Additional file 1: Figure S1J).

\section{Endogenously expressed UPA and UPAR are required for Plg-induced cytokine expression by $\mathrm{N}$-astrocytes}

AMD is a specific inhibitor of uPA enzymatic activity that does not affect the activity of tPA [42]. To identify the plasminogen activator expressed by $\mathrm{N}$-astrocytes and responsible for converting $\mathrm{Plg}$ into an astrocyteactivating agent, cells were incubated with $\mathrm{Plg}$, Plg plus tPA, or vehicle in presence or absence of AMD. AMD blocked expression of TNF $\alpha$, IL-1 $1 \beta$, and CCL2 in Nastrocytes treated with $\mathrm{Plg}$ alone, but not in cells treated with Plg plus tPA (Fig. 5a-c). These results suggest that the endogenous Plg activator in $\mathrm{N}$-astrocytes is uPA. In I $\mathrm{B} \alpha$ phosphorylation studies, AMD had the same effect, inhibiting the response to $\mathrm{Plg}$ alone but not to Plg plus tPA (Fig. 5d, Additional file 1: Figure S1K).

uPAR promotes Plg activation by uPA and also directly triggers cell-signaling in response to uPA [15]. To test whether UPAR is necessary in the pathway by which 


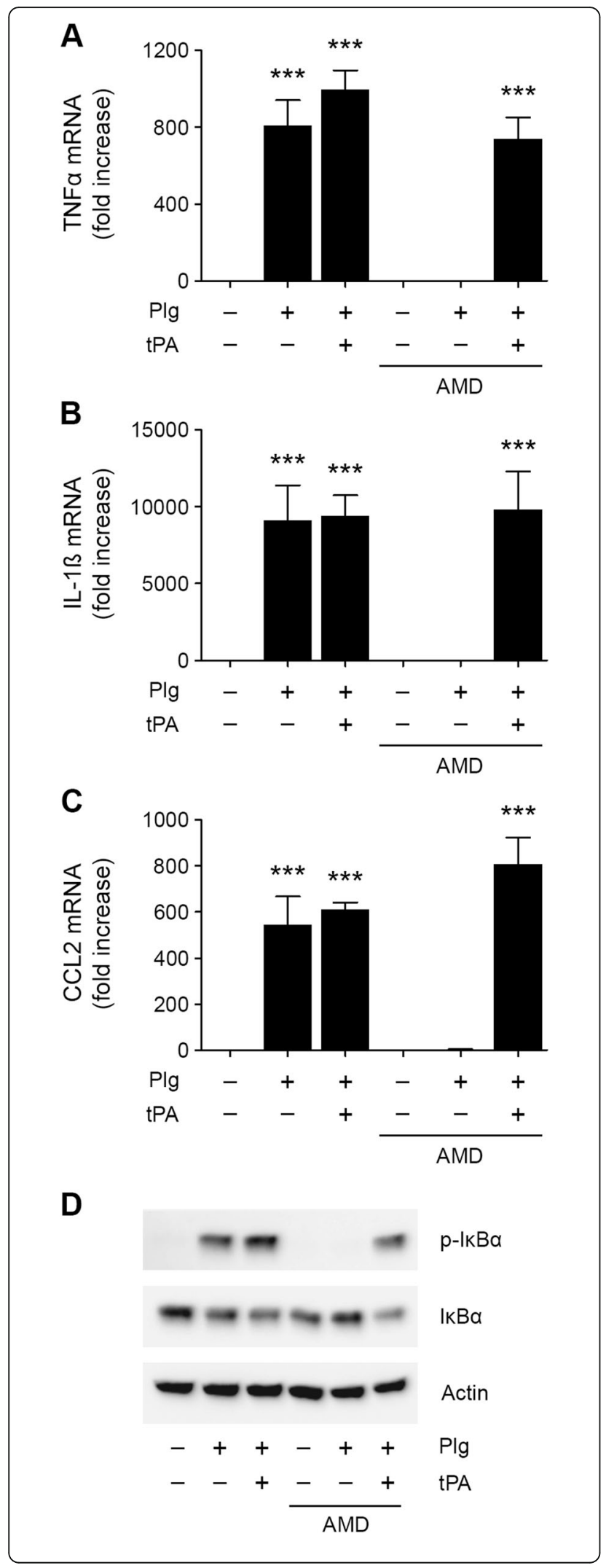

Fig. 5 a-d N-astrocytes produce uPA to activated Plg endogenously. $\mathrm{N}$-astrocytes were treated for $6 \mathrm{~h}$ with Plg $(0.2 \mu \mathrm{M})$, Plg plus tPA $(12 \mathrm{nM})$, or vehicle in the presence or absence of amiloride (AMD, $100 \mu \mathrm{M})$. RT-qPCR was performed to determine mRNA levels for TNFa, IL-1 $\beta$, and CCL2 (mean $\pm \mathrm{SEM} ; n=3$; ${ }^{* * *} p<$ $0.001,{ }^{* *} p<0.01$; one-way ANOVA with Tukey's post hoc test). $\mathbf{d} \mathrm{N}$ astrocytes were treated with $(0.2 \mu \mathrm{M})$, Plg plus tPA $(12 \mathrm{nM})$, or vehicle in presence and absence of amiloride $(100 \mu \mathrm{M})$ for $1 \mathrm{~h}$. Immunoblot analysis was performed to detect phospho-IKBa, IKBa, and $\beta$-actin

Plg induces pro-inflammatory cytokine expression by Nastrocytes, we treated $\mathrm{N}$-astrocytes with $\mathrm{Plg}$ alone, $\mathrm{Plg}$ plus tPA, or vehicle in the presence of UPAR-specific antibody or non-specific IgG. uPAR-specific antibody neutralized the effects of Plg on expression of TNF- $\alpha$, IL-1 $\beta$, and CCL2 but did not inhibit cytokine expression in response to Plg plus tPA (Fig. 6a-c). Non-specific IgG was without effect. uPAR-specific antibody also inhibited $\mathrm{IKB} \alpha$ phosphorylation selectively in response to $\mathrm{Plg}$ alone but not Plg plus tPA (Fig. 6d, Additional file 1: Figure S1L). Thus, uPAR plays an essential role in the pathway by which Plg stimulates pro-inflammatory cytokine expression in $\mathrm{N}$-astrocytes in the absence of exogenously added Plg activator.

The uPA ATF inhibits Plg-induced $\mathrm{N}$-astrocyte activation The UPA ATF binds to uPAR, similarly to full-length uPA, and reproduces the signaling responses elicited when uPA binds to UPAR [24-26]. To determine whether UPAR functions in promoting Plg-induced cytokine expression by $\mathrm{N}$-astrocytes by facilitating Plg activation or through uPAR-initiated cell-signaling, we treated $\mathrm{N}$-astrocytes with $\mathrm{Plg}$ in the presence of increasing concentrations of uPA ATF. Figures $7 \mathrm{a}-\mathrm{c}$ show that the uPA ATF inhibited the effects of Plg on expression of TNF $\alpha$, IL-1 $\beta$, and CCL2; the activity of the uPA ATF was ATF-concentration-dependent. The uPA ATF also inhibited IкB $\alpha$ phosphorylation in $\mathrm{N}$-astrocytes in response to Plg (Fig. 7d, Additional file 1: Figure S1M). These results suggest that the principal activity of uPAR is to facilitate Plg activation by endogenously produced uPA and not to trigger cell-signaling. uPA ATF probably functions by competitively displacing uPA from uPAR, which disrupts the Plg activation receptor complex.

\section{Discussion}

Neuro-inflammation is increasingly recognized as an important regulator of diverse neurological diseases, including multiple sclerosis, Alzheimer's disease, other forms of neurodegeneration, traumatic brain injury, ischemic stroke, and central sensitization in pain processing $[1,2,43-46]$. While the role of microglia in neuro-inflammation is well recognized, astrocytes also are major contributors, especially in 

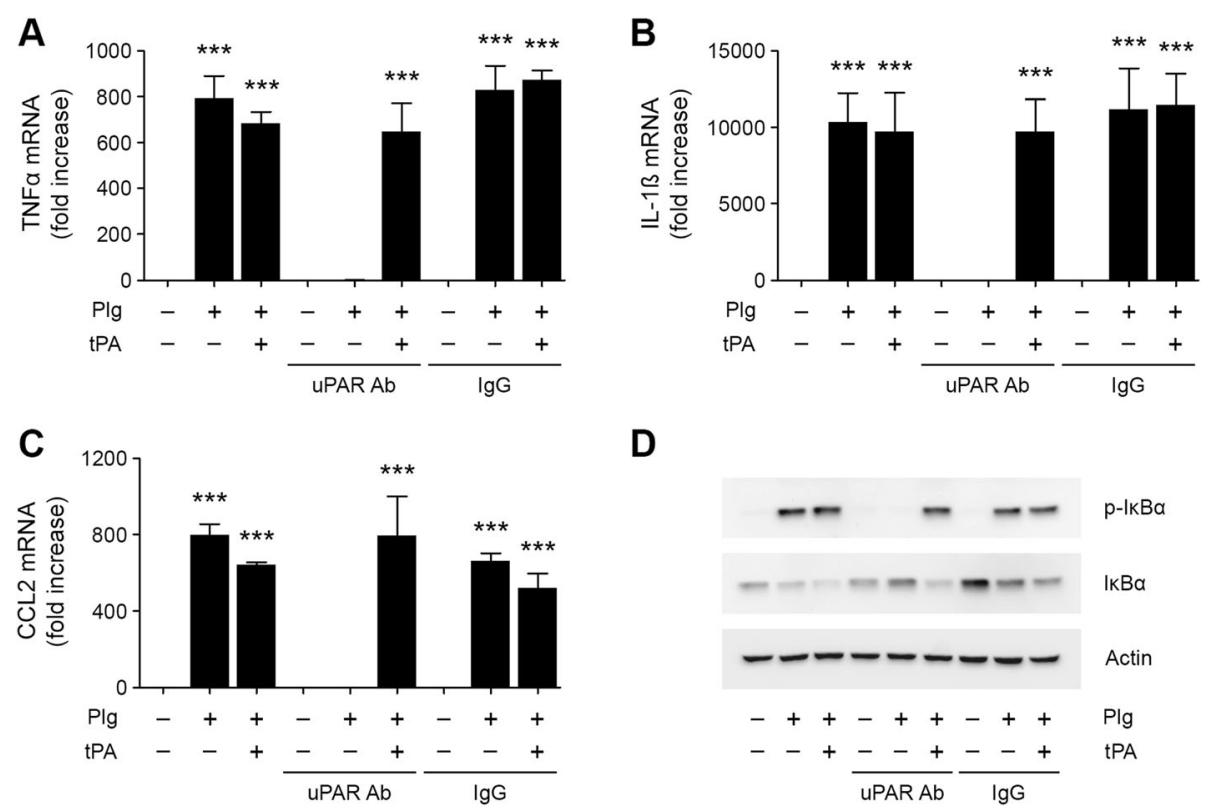

D

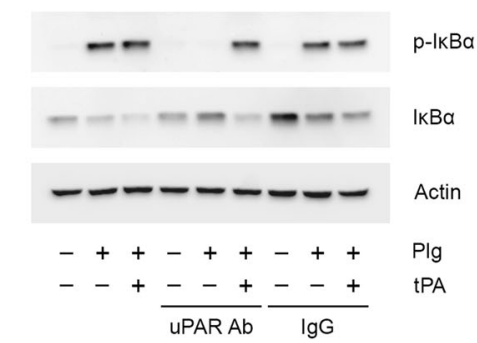

Fig. 6 UPAR-specific antibody neutralizes the effects of Plg on cytokine expression by N-astrocytes. (a-c) N-astrocytes were treated with Plg $(0.2 \mu \mathrm{M})$, Plg plus tPA $(12 \mathrm{nM})$, or vehicle in presence and absence of uPAR-specific antibody $(1 \mu \mathrm{g} / \mathrm{mL})$ or an equivalent concentration of nonspecific lgG for $6 \mathrm{~h}$. Expression of TNFa, IL-1 $\beta$, and CCL2 was determined by RT-qPCR (mean \pm SEM; $n=3 ;{ }^{* * *} p<0.001$; one-way ANOVA with Tukey's post hoc test. Statistical analysis is relative to the vehicle control). $\mathbf{d}$ N-astrocytes were treated with Plg $(0.2 \mu \mathrm{M})$, Plg plus tPA (12 nM) or vehicle in presence and absence of UPAR-specific antibody $(1 \mu \mathrm{g} / \mathrm{mL})$ or an equivalent concentration of non-specific IgG. Immunoblot analysis was performed to detect phospho-IKBa, IKBa and $\beta$-actin

chronic CNS inflammatory states, despite their more limited repertoire of TLRs and other PRRs $[1,2,5,6]$.

There is considerable evidence that activation of fibrinolysis may contribute to neuro-inflammation. When LPS is injected into the hippocampus of Plg gene knockout mice, the inflammatory response within the brain is attenuated [47]. In experimental autoimmune encephalomyelitis (EAE), an accepted model of multiple sclerosis, Plg gene knock-out mice develop delayed disease of lesser severity [48]. Furthermore, depleting Plg outside the CNS, using antisense oligonucleotide (ASO) technology, decreases the severity of pathology in a mouse model of Alzheimer's Disease [49]. In this latter study, complex mechanisms may be operational because the ASO approach does not appear to affect $\mathrm{Plg}$ levels within the CNS. Although Plg is expressed mainly by the liver, other cells and tissues, including CNS cells, express Plg [50].

The role of uPA and uPAR in neuro-inflammation appears more context-specific. Expression of uPA in the CNS is increased in neuro-inflammation [51]. Furthermore, in ischemic brain injury, binding of uPA expressed by neurons to astrocytic UPAR results in uPAR-initiated cell-signaling and astrocytic activation [23]. However, UPA and UPAR appear to be protective in EAE [52], as opposed the exacerbating role that would be predicted if the major role of uPA and UPAR is Plg activation [48].
The results presented herein demonstrate that PM generation induces expression of the potently proinflammatory cytokines, TNF $\alpha$, IL- $1 \beta$, and CCL2, in microglia and astrocytes. In $\mathrm{N}$-astrocytes, the pathway by which Plg increases cytokine expression is tightly controlled by a series of fibrinolysis receptors, including the Plg receptor, $\alpha$-enolase, $u$ PAR, and PAR-1. $\alpha$-enolase and UPAR appear to function mainly to amplify Plg activation, implicating PAR-1 as the major signal transduction initiator. The ability of the ATF to block cytokine expression by Plg in $\mathrm{N}$-astrocytes, suggests that uPARinitiated cell-signaling is not sufficient in and of itself to activate these astrocytes. Our results with the uPA ATF do not rule out the possibility that when $\mathrm{N}$-astrocytes produce uPA endogenously, uPAR-associated uPA has the dual role of promoting Plg activation, which is essential for cytokine induction, and triggering UPAR signaling, which may regulate the degree of astrocytic activation, as previously observed [23]. Figure 8 presents a model showing how three distinct fibrinolysis receptors work in concert to promote astrocytic activation in response to Plg. Multiple targets for antagonizing this pathway are identified.

$\mathrm{N}$-astrocytes differed from microglia in culture and from cultured BMDMs, studied previously [21], in that Plg-induced cytokine expression independently of exogenously added Plg activator. This result reflects the 


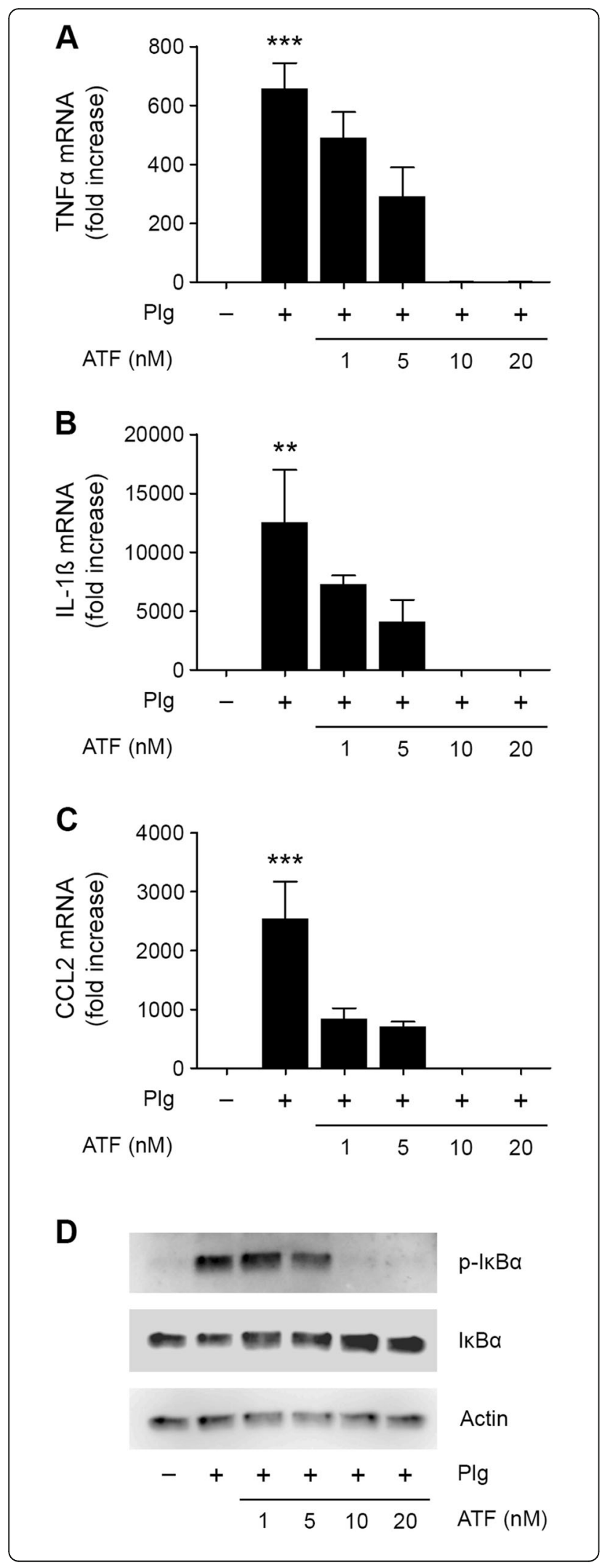

Fig. 7 The uPA ATF blocks cytokine expression by $\mathrm{N}$-astrocytes in response to Plg. a-c N-astrocytes were treated for $6 \mathrm{~h}$ with Plg $(0.2 \mu \mathrm{M})$ and the indicated concentrations of UPA ATF. Expression of TNFa, IL-1 $\beta$, and CCL2 was determined by RT-qPCR (mean \pm SEM; $n$ $=3$; ${ }^{* *} p<0.001$; one-way ANOVA with Tukey's post hoc test. Statistical analysis is relative to the vehicle control). $\mathbf{d} \mathrm{N}$-astrocytes were treated for $1 \mathrm{~h}$ with Plg $(0.2 \mu \mathrm{M})$ and the indicated concentrations of UPA ATF. Immunoblot analysis was performed to detect phospho-IKBa, IKBa, and $\beta$-actin

ability of $\mathrm{N}$-astrocytes in culture to express uPA and activate Plg in the absence of added tPA. In intact brain, astrocytic expression of uPA may be highest during development and then decrease [53]. However, in a tissue, as opposed to cell culture, astrocytic uPAR has the capacity to ligate uPA derived from any cell type in the cellular microenvironment. Thus, in various forms of pathology, the pathway described here may become operational due to astrocytic loading of uPAR with uPA produced by other cell types such as uPA [23].

$\mathrm{N}$-astrocytes also differed from microglia and cultured BMDMs in that these cells demonstrated limited responsiveness to TLR agonists. In our studies, $\mathrm{N}$-astrocytes failed to express increased levels of pro-inflammatory cytokines in response to agonists for TLR2, TLR4, and TLR9. Farina et al. showed that human astrocytes express TLR3 [7]. These same investigators were unable to demonstrate astrocytic expression of TLR2, TLR4, or TLR9. However, others have shown that expression of some TLRs may be increased when astrocytes are activated $[54,55]$. Understanding how the activity of well described pattern recognition receptors and fibrinolysis receptors are integrated in the function of astrocytes in innate immunity is an important topic for future work.

LDL Receptor-related Protein-1 (LRP1) is a tPA receptor not studied here; however, its activity in promoting tPA endocytosis by astrocytes is previously reported [56]. Based on its ability to clear tPA from the astrocytic cell-surface, LRP1 has the capacity to regulate the amount of tPA available for Plg activation. LRP1 also may regulate the abundance of cell-surface uPAR via endocytosis [57]. Either of these mechanisms may regulate astrocytic activation and expression of pro-inflammatory cytokines by astrocytes in vivo.

Our results identifying $\alpha$-enolase and not actin as a cell-surface Plg receptor in astrocytes contrast with previous results supporting a role for actin [39]. An important difference in the two studies; however, may be the major plasminogen activator considered. In the previous study, actin was identified as essential in promoting Plg activation by tPA. In the pathway by which Plg leads to cytokine expression, studied here, uPA appeared to be the essential Plg activator. Although actin-specific antibody did not inhibit cytokine expression in our 


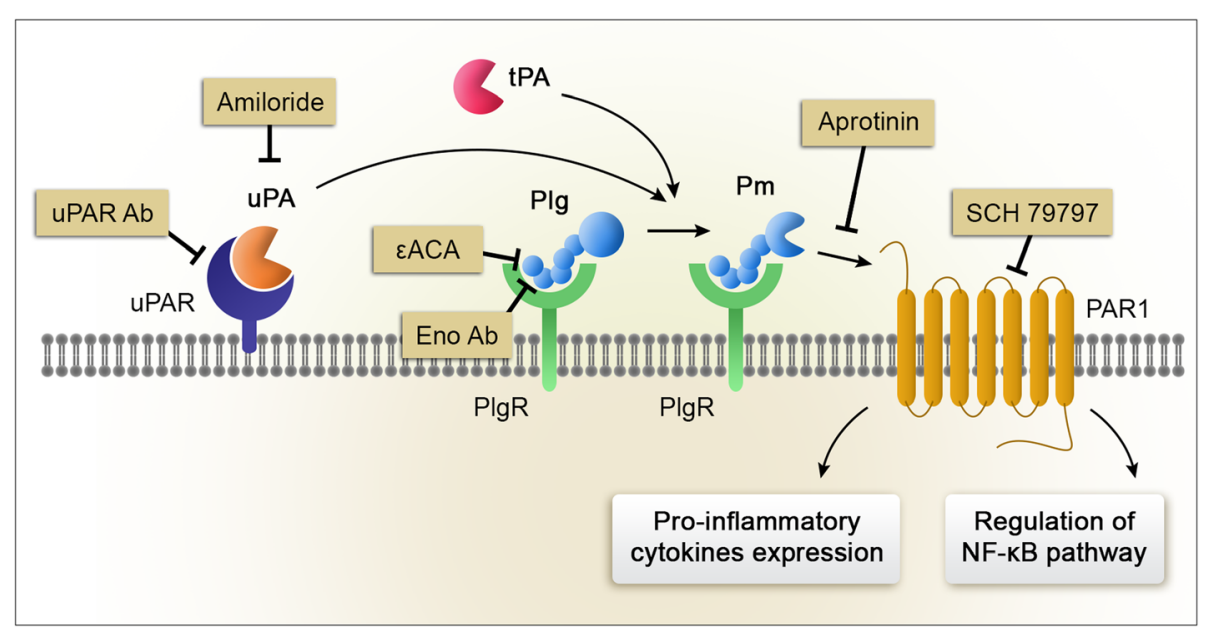

Fig. 8 Model showing the orchestrated action of fibrinolysis receptors in the induction of cytokine expression by Plg in N-astrocytes. Multiple targets for antagonizing this pathway are identified

experiments in which cells were treated with Plg plus tPA, it is still possible that distinct Plg receptors function in astrocytes to promote Plg activation by tPA or uPA. PAR-1 is best known for its function as a thrombin receptor, which informs cells that coagulation has been activated; however, PAR-1 is proteolytically activated by other proteases as well, including plasmin [58, 59]. In monocytes and macrophages, PM-mediated PAR cleavage is pro-inflammatory [18-21]. We concluded that a PAR and probably PAR-1 is the ultimate signal transducer responsible for the response to $\mathrm{PM}$ in $\mathrm{N}$-astrocytes based on studies with the PAR-1-specific inhibitor, SCH 79797. This reagent completely blocked expression of TNF $\alpha$, IL-1 $\beta$, and CCL2 in response to Plg. PAR-1 may be a target for inhibiting neuro-inflammation. Because the pathway by which Plg causes pro-inflammatory cytokine expression by $\mathrm{N}$-astrocytes is linear, in addition to PAR-1, the other two required fibrinolysis receptors in this pathway, $\alpha$-enolase and uPAR, also may be targets for inhibiting the activity of PM. The effectiveness of targeting uPAR was demonstrated here in studies with uPARspecific antibody and the uPA ATF. Hypothetically, opposing astrocytic activation may attenuate the crosstalk with microglia and other CNS cells, which adds to the chronicity of inflammation.

\section{Conclusions}

In the CNS, activation of astrocytes leads to crosstalk with cells such as microglia and contributes to chronic neuroinflammation. Compared with microglia, astrocytes express a less robust continuum of Pattern Recognition Receptors. We describe a pathway by which the zymogen form of the fibrinolysis protease, plasminogen, causes astrocytic activation and expression of pro-inflammatory cytokines, including TNF- $\alpha, \mathrm{IL}-1 \beta$, and CCL2. The pathway requires a series of receptors for fibrinolysis proteins, including $\alpha$-enolase, uPAR, and PAR-1. Targeting any of these receptors on astrocytes blocked the pro-inflammatory activity of plasminogen. Fibrinolysis protease receptors may be targets for inhibiting neuro-inflammation.

\section{Supplementary information}

Supplementary information accompanies this paper at https://doi.org/10. 1186/s12974-019-1657-3.

Additional file 1: Figure S1. (A-C) N-astrocytes were serum-starved for $30 \mathrm{~min}$ and then treated for $6 \mathrm{~h}$ with Plg alone or with Plg $(0.2 \mu \mathrm{M})$ plus tPA (12 nM), or with vehicle. Expression of the mRNAs encoding TNFa, IL$1 \beta$ and CCL2 was determined using RPL13A or SDHA as APCR normalizers. (D-M) Densitometric analysis of the immunoblots presented in the paper.

\section{Abbreviations}

AMD: Amiloride; ATF: Amino terminal fragment of UPA; BMDMs: Bone Marrow-derived macrophages; CCL2: Chemokine (C-C motif) ligand 2; EACA: $\varepsilon$-Aminocaproic acid; GAPDH: Glyceraldehyde 3-phosphate dehydrogenase; GPI: Glycosylphosphatidylinositol; IL-1ß: Interleukin-1ß; LPS: Lipopolysaccharide; LTA: Lipoteichoic acid; NFkB: Nuclear Factor kappalight-chain-enhancer of activated B cells; NMDA-R: N-methyl-D-aspartate Receptor; ODN: Oligodeoxynucleotide; PAR: Protease-activated Receptor; PL: Plasmin; Plg: Plasminogen; TLRs: Toll-Like receptors; TNFa: Tumor necrosis factor-a; tPA: Tissue-type plasminogen activator; uPA: Urokinase-type plasminogen activator

\section{Acknowledgements}

Not applicable

\section{Authors' contributions}

PP, MAB, CaZ, CrZ, PA, and EM conducted experiments. MZK, SLG, and EM supervised the work. All authors contributed to experimental design and results interpretation. PP, SLG, and EM wrote the paper. All authors read and approved the final manuscript.

\section{Funding}

Support for this work was provided by National Institutes of Health grant R01 HL136395 to S.L.G. S.L.G. also was supported by NIH grant R01 NS097590. P.P. and C.Z. were partially supported by the Ministry of Education, Universities and Research, Italy, grant FIRB 2013 RBFR13RBK9 to E.M. 


\section{Availability of data and materials}

Not applicable

\section{Ethics approval and consent to participate \\ Not applicable}

\section{Consent for publication}

Not applicable

\section{Competing interests}

The authors declare that they have no competing interests.

\section{Author details}

'The Department of Pathology, University of California San Diego, 9500 Gilman Drive, La Jolla, CA 92093-0612, USA. ${ }^{2}$ The Department of Experimental Medicine, Sapienza University of Rome, 00161 Rome, Italy. ${ }^{3}$ The Department of Chemical Sciences and Technologies, Tor Vergata University of Rome, 00133 Rome, Italy.

\section{Received: 20 August 2019 Accepted: 25 November 2019}

\section{Published online: 06 December 2019}

\section{References}

1. McGeer PL, McGeer EG. The inflammatory response system of brain: implications for therapy of Alzheimer and other neurodegenerative diseases. Brain Res. Rev. 1995:195-218.

2. Karve IP, Taylor JM, Crack PJ. The contribution of astrocytes and microglia to traumatic brain injury. Br J Pharmacol. 2016;173:692-702.

3. Block ML, Zecca L, Hong JS. Microglia-mediated neurotoxicity: uncovering the molecular mechanisms. Nat. Rev. Neurosci. 2007:57-69.

4. Olson JK, Miller SD. Microglia initiate central nervous system innate and adaptive immune responses through multiple TLRs. J Immunol. 2004;173: 3916-24.

5. Holm TH, Draeby D, Owens T. Microglia are required for astroglial toll-like receptor 4 response and for optimal TLR2 and TLR3 response. Glia. 2012;60: 630-8.

6. Jack CS, Arbour N, Manusow J, Montgrain V, Blain M, McCrea E, et al. TLR signaling tailors innate immune responses in human microglia and astrocytes. J Immunol. 2005;175:4320-30.

7. Farina C, Krumbholz M, Giese T, Hartmann G, Aloisi F, Meinl E. Preferential expression and function of Toll-like receptor 3 in human astrocytes. J Neuroimmunol. 2005;159:12-9.

8. Mackman N. Role of tissue factor in hemostasis, thrombosis, and vascular development. Arterioscler. Thromb. Vasc. Biol. 2004:1015-22.

9. Altieri DC, Plescia J, Plow EF. The structural motif glycine 190-valine 202 of the fibrinogen gamma chain interacts with CD11b/CD18 integrin (alpha M beta 2, Mac-1) and promotes leukocyte adhesion. J Biol Chem. 1993;268: $1847-53$

10. Joyce DE, Gelbert L, Ciaccia A, DeHoff B, Grinnell BW. Gene expression profile of Antithrombotic Protein C defines new mechanisms modulating inflammation and apoptosis. J Biol Chem. 2001;276:11199-203.

11. Esmon CT. The interactions between inflammation and coagulation. Br. J. Haematol. 2005:417-30.

12. Castellino FJ, Ploplis VA. Structure and function of the plasminogen/plasmin system. Thromb. Haemost. 2005:647-54

13. Chapin JC, Hajjar KA. Fibrinolysis and the control of blood coagulation. Blood Rev. 2015;29:17-24.

14. Miles L, Parmer R. Plasminogen receptors: the first quarter century. Semin. Thromb. Hemost. 2013:329-37.

15. Blasi F, Carmeliet P. UPAR: a versatile signalling orchestrator. Nat. Rev. Mol. Cell Biol. 2002:932-43.

16. Mantuano E, Lam MS, Gonias SL. LRP1 assembles unique co-receptor systems to initiate cell signaling in response to tissue-type plasminogen activator and myelin-associated glycoprotein. J Biol Chem. 2013;288:34009-18.

17. Mantuano E, Azmoon P, Brifault C, Banki MA, Gilder AS, Campana WM, et al. Tissue-type Plasminogen Activator Regulates Macrophage Activation and Innate Immunity. Blood. 2017;130:blood-2017-04-780205.

18. Bock A, Tucker N, Kelher MR, Khan SY, Gonzalez E, Wohlauer M, et al. aEnolase causes proinflammatory activation of pulmonary microvascular endothelial cells and primes neutrophils through plasmin activation of protease-activated receptor 2. Shock. 2015;44:137-42.
19. Kamio N, Hashizume H, Nakao S, Matsushima K, Sugiya H. Plasmin is involved in inflammation via protease-activated receptor-1 activation in human dental pulp. Biochem Pharmacol. 2008;75:1974-80.

20. Carmo AAF, Costa BRC, Vago JP, de Oliveira LC, Tavares LP, Nogueira CRC, et al. Plasmin induces in vivo monocyte recruitment through ProteaseActivated Receptor-1-, MEK/ERK-, and CCR2-Mediated Signaling. J Immunol. 2014;193:3654-63.

21. Zalfa C, Azmoon P, Mantuano E, Gonias SL. Tissue-type plasminogen activator neutralizes LPS but not protease-activated receptor-mediated inflammatory responses to plasmin. J Leukoc Biol. 2019;105:729-40.

22. Maeda S, Nakajima K, Tohyama Y, Kohsaka S. Characteristic response of astrocytes to plasminogen/plasmin to upregulate transforming growth factor beta 3 (TGFB3) production/secretion through proteinase-activated receptor-1 (PAR-1) and the downstream phosphatidylinositol 3-kinase (PI3K)-Akt/PKB signa. Brain Res. 2009:1305:1-13.

23. Diaz A, Merino P, Manrique LG, Ospina JP, Cheng L, Wu F, et al. A cross talk between neuronal urokinase-type plasminogen activator (UPA) and astrocytic UPA receptor (UPAR) promotes astrocytic activation and synaptic recovery in the ischemic brain. J Neurosci. 2017:37:10310-22.

24. Stahl A, Mueller BM. Binding of urokinase to its receptor promotes migration and invasion of human melanoma cells in vitro. Cancer Res. 1994 54:3066-71

25. Nguyen DHD, Hussaini IM, Gonias SL. Binding of urokinase-type plasminogen activator to its receptor in MCF-7 cells activates extracellular signal-regulated kinase 1 and 2 which is required for increased cellular motility. J Biol Chem. 1998;273:8502-7.

26. Rabbani SA, Gladu J, Mazar AP, Henkin J, Goltzman D. Induction in human osteoblastic cells ( $\mathrm{SaOS} 2$ ) of the early response genes fos, jun, and myc by the amino terminal fragment (ATF) of urokinase. J Cell Physiol. 1997;172:137-45.

27. Gonias SL, Braud LL, Geary WA, VandenBerg SR. Plasminogen binding to rat hepatocytes in primary culture and to thin slices of rat liver. Blood. 1989;74:729-36.

28. Ni M, Aschner M. Neonatal rat primary microglia: Isolation, culturing, and selected applications. Toxicol: Curr. Protoc; 2010.

29. Mantuano E, Brifault C, Lam MS, Azmoon P, Gilder AS, Gonias SL. LDL receptor-related protein-1 regulates NFKB and microRNA-155 in macrophages to control the inflammatory response. Proc Natl Acad Sci U S A. 2016:113:1369-74.

30. Miles LA, Levin EG, Plescia J, Collen D, Plow EF. Plasminogen receptors, urokinase receptors, and their modulation on human endothelial cells. Blood. 1988:72:628-35

31. Hoshino K, Takeuchi O, Kawai T, Sanjo H, Ogawa T, Takeda Y, et al. Cutting edge: Toll-like receptor 4 (TLR4)-deficient mice are hyporesponsive to lipopolysaccharide: evidence for TLR4 as the Lps gene product. J Immunol. 1999:162:3749-52

32. Schwandner $R$, Dziarski $R$, Wesche $H$, Rothe $M$, Kirschning CJ. Peptidoglycanand lipoteichoic acid-induced cell activation is mediated by Toll-like receptor 2. J Biol Chem. 1999;274:17406-9.

33. Stevens SL, Ciesielski TMP, Marsh BJ, Yang T, Homen DS, Boule JL, et al. Tolllike receptor 9: a new target of ischemic preconditioning in the brain. $J$ Cereb Blood Flow Metab. 2008:28:1040-7.

34. Karin M, Ben-Neriah Y. Phosphorylation Meets Ubiquitination: The Control of NF-kB Activity. Annu Rev Immunol. 2000;18:621-63.

35. Zhang Y, Zhou Z-H, Bugge TH, Wahl LM. Urokinase-type plasminogen activator stimulation of monocyte matrix metalloproteinase-1 production is mediated by plasmin-dependent signaling through annexin A2 and inhibited by inactive plasmin. J Immunol. 2007;179:3297-304

36. Plow EF, Miles LA, Dahlberg CM, Plescia J, Felez J, Kato K. Role of cell-surface lysines in plasminogen binding to cells: identification of a-enolase as a candidate plasminogen receptor. Biochemistry. 1991;30:1682-91.

37. Pancholi V. Multifunctional a-enolase: its role in diseases. Cell. Mol. Life Sci. 2001. p. 902-920.

38. Díaz-Ramos À, Roig-Borrellas A, García-Melero A, López-Alemany R. aenolase, a multifunctional protein: its role on pathophysiological situations. J. Biomed. Biotechnol. 2012;2012:156795.

39. Briens A, Bardou I, Lebas H, Miles LA, Parmer RJ, Vivien D, et al. Astrocytes regulate the balance between plasminogen activation and plasmin clearance via cell-surface actin. Cell Discov. Nature Publishing Groups. 2017:3.

40. Junge CE, Lee CJ, Hubbard KB, Zhang Z, Olson JJ, Hepler JR, et al. Proteaseactivated receptor-1 in human brain: localization and functional expression in astrocytes. Exp Neurol. 2004;188:94-103. 
41. Nicole O, Goldshmidt A, Hamill CE, Sorensen SD, Sastre A, Lyuboslavsky P, et al. Activation of protease-activated receptor-1 triggers astrogliosis after brain injury. J Neurosci. 2005;25:4319-29.

42. Vassalli JD, Belin D. Amiloride selectively inhibits the urokinase-type plasminogen activator. FEBS Lett. 1987;214:187-91.

43. Van Winsen LML, Polman CH, Dijkstra CD, Tilders FJH, Uitdehaag BMJ. Multiple sclerosis multiple sclerosis. Mult Scler. 2010;391:4-7.

44. Dirnagl U, ladecola C, Moskowitz MA. Pathobiology of ischaemic stroke: An integrated view. Trends Neurosci. 1999:391-7.

45. Latremoliere A, Woolf CJ. Central sensitization: a generator of pain hypersensitivity by central neural plasticity. J. Pain. 2009:895-926.

46. Woolf CJ. Central sensitization: implications for the diagnosis and treatment of pain. Pain. 2011;152:S2-15.

47. Hultman K, Cortes-Canteli M, Bounoutas A, Richards AT, Strickland S, Norris EH. Plasmin deficiency leads to fibrin accumulation and a compromised inflammatory response in the mouse brain. J Thromb Haemost. 2014;12: 701-12.

48. Shaw MA, Gao Z, McElhinney KE, Thornton S, Flick MJ, Lane A, et al. Plasminogen deficiency delays the onset and protects from demyelination and paralysis in autoimmune neuroinflammatory disease. J Neurosci. 2017; 37:3776-88.

49. Baker SK, Chen ZL, Norris EH, Revenko AS, MacLeod AR, Strickland S. Bloodderived plasminogen drives brain inflammation and plaque deposition in a mouse model of Alzheimer's disease. Proc Natl Acad Sci U S A. 2018;115: E9687-96.

50. Zhang L, Seiffert D, Fowler BJ, Jenkins GR, Thinnes TC, Loskutoff DJ, et al. Plasminogen has a broad extrahepatic distribution. Thromb Haemost. 2002; 87:493-501.

51. Cunningham O, Campion S, Hugh Perry V, Murray C, Sidenius N, Docagne F, et al. Microglia and the urokinase plasminogen activator receptor/uPA system in innate brain inflammation. Glia. 2009;57:1802-14.

52. Gur-Wahnon D, Mizrachi T, Maaravi-Pinto FY, Lourbopoulos A, Grigoriadis N, Higazi AAR, et al. The plasminogen activator system: Involvement in central nervous system inflammation and a potential site for therapeutic intervention. J Neuroinflammation. 2013;10.

53. Kalderon N, Ahonen K, Fedoroff S. Developmental transition in plasticity properties of differentiating astrocytes: Age related biochemical profile of plasminogen activators in astroglial cultures. Glia. 1990;3:413-26.

54. Tarassishin L, Suh HS, Lee SC. LPS and IL-1 differentially activate mouse and human astrocytes: Role of CD14, vol. 62. John Wiley and Sons Inc: Glia; 2014. p. 999-1013.

55. Carpentier PA, Begolka WS, Olson JK, Elhofy A, Karpus WJ, Miller SD. Differential activation of astrocytes by innate and adaptive immune stimuli. Glia. 2005:49:360-74.

56. Cassé F, Bardou I, Danglot L, Briens A, Montagne A, Parcq J, et al. Glutamate controls tPA recycling by astrocytes, which in turn influences glutamatergic signals. J Neurosci. Society for Neuroscience. 2012;32:5186-99.

57. L.Gonias S, Gaultier A, Jo M. Regulation of the Urokinase Receptor (UPAR) by LDL Receptor-related Protein-1 (LRP1). Curr Pharm Des. Bentham Science Publishers Ltd. 2011;17:1962-9.

58. Coughlin SR. Thrombin signalling and protease-activated receptors. Nature. 2000:258-64.

59. Kuliopulos A, Covic L, Seeley SK, Sheridan PJ, Helin J, Costello CE. Plasmin desensitization of the PAR1 thrombin receptor: Kinetics, sites of truncation, and implications for thrombolytic therapy. Biochemistry. 1999:38:4572-85.

\section{Publisher's Note}

Springer Nature remains neutral with regard to jurisdictional claims in published maps and institutional affiliations.

Ready to submit your research? Choose BMC and benefit from:

- fast, convenient online submission

- thorough peer review by experienced researchers in your field

- rapid publication on acceptance

- support for research data, including large and complex data types

- gold Open Access which fosters wider collaboration and increased citations

- maximum visibility for your research: over $100 \mathrm{M}$ website views per year

At $\mathrm{BMC}$, research is always in progress.

Learn more biomedcentral.com/submissions 